\title{
Halorubrum alkaliphilum sp. nov., a novel haloalkaliphile isolated from a soda lake in Xinjiang, China
}

Correspondence

Shuang-Jiang Liu

shuangjiang@hotmail.com

\author{
Jie Feng, ${ }^{1}$ Peijin Zhou, ${ }^{1}$ Yu-Guang Zhou, ${ }^{1}$ Shuang-Jiang Liu ${ }^{1}$ \\ and Kimberly Warren-Rhodes ${ }^{2}$
${ }^{1}$ State Key Laboratory for Microbial Resources, Institute of Microbiology, Chinese Academy of Sciences, ZhongGuanCun, Haidian, Beijing 100080, PR China
${ }^{2}$ Ecosystem Sciences Division, Department of Environmental Science, Policy and Management, University of California at Berkeley, CA 94720, USA

\begin{abstract}
A novel haloalkaliphilic archaeon, strain $\mathrm{DZ}-1^{\top}$, was isolated from a soda lake in Xinjiang, China. The taxonomy of strain $\mathrm{DZ}-1^{\top}$ was studied by polyphasic methods. According to $16 \mathrm{~S}$ rRNA gene sequence similarity, strain $\mathrm{DZ}-1^{\top}$ was phylogenetically related to Halorubrum tibetense (97.5\%), Halorubrum vacuolatum (95.7\%) and Halorubrum saccharovorum (95.9\%). Strain DZ-1 ${ }^{\top}$ was able to grow at $20-44{ }^{\circ} \mathrm{C}$ and was also physiologically different from the above-mentioned species with respect to assimilation of sugars and utilization of organic acids. The DNA G +C content of strain DZ-1 ${ }^{\top}$ was $62 \cdot 1 \mathrm{~mol} \%\left(T_{\mathrm{m}}\right)$. The DNA-DNA relatedness of strain DZ-1 ${ }^{\top}$ to $H$. tibetense and $H$. vacuolatum was 22 and $13 \%$, respectively. It was concluded that strain DZ-1 ${ }^{\top}$ represents a novel species of the genus Halorubrum, for which the name Halorubrum alkaliphilum (type strain, $\mathrm{DZ}-1^{\top}=\mathrm{AS} 1.3528^{\top}=\mathrm{JCM} 12358^{\top}$ ) is proposed.
\end{abstract}

Species of the genus Halorubrum (McGenity \& Grant, 1995) can be classified into two groups according to their growth $\mathrm{pH}$ ranges and origins. Group 1 includes species that cannot grow at $\mathrm{pH} 10 \cdot 5$, such as Halorubrum sodomense (Oren, 1983), Halorubrum lacusprofundi (Franzmann et al., 1988), Halorubrum saccharovorum (Tomlinson \& Hochstein, 1976), Halorubrum trapanicum (McGenity \& Grant, 1995), Halorubrum coriense (Kamekura \& Dyall-Smith, 1995), Halorubrum distributum (Oren et al., 1997b), Halorubrum tebenquichense (Lizama et al., 2002), Halorubrum terrestre (Ventosa et al., 2004) and Halorubrum xinjiangense (Feng et al., 2004). Group 2 contains the haloalkaliphiles that are able to grow at $\mathrm{pH} 10.5$ and are from soda lakes, currently with only two species, Halorubrum vacuolatum (Kamekura et al., 1997) and Halorubrum tibetense (Fan et al., 2004). This grouping is supported by phylogenetic analysis based on $16 \mathrm{~S}$ rRNA gene sequences (Fig. 1). 16S rRNA gene sequence similarities among the recognized members of groups 1 and 2 are less than $96.5 \%$. During our screening for archaerhodopsin-producers, a haloalkaliphilic archaeon, strain DZ-1 ${ }^{\mathrm{T}}$, was obtained. In this report, we present the identification and characterization of this strain.

Strain DZ- $1^{\mathrm{T}}$ was isolated from a sludge sample from a soda

Published online ahead of print on 30 July 2004 as DOI 10.1099/ ijs.0.63320-0.

The GenBank/EMBL/DDBJ accession number for the 16S rRNA gene sequence of strain $\mathrm{DZ}-1^{\top}$ is $A Y 510708$. lake in Xinjiang, China by enrichment and subsequently plating the enriched cultures on agar medium containing the following ingredients $\left(\mathrm{l}^{-1}\right): 7 \cdot 5 \mathrm{~g}$ Casamino acid, $10 \cdot 0 \mathrm{~g}$ yeast extract, $3.0 \mathrm{~g}$ trisodium citrate, $200 \mathrm{~g} \mathrm{NaCl}, 2.0 \mathrm{~g}$ $\mathrm{KCl}, 1.0 \mathrm{~g} \mathrm{MgSO}_{4} .7 \mathrm{H}_{2} \mathrm{O}, 0.2 \mathrm{mg} \mathrm{MnSO}_{4} .7 \mathrm{H}_{2} \mathrm{O}, 0.05 \mathrm{~g}$ $\mathrm{FeSO}_{4} \cdot 7 \mathrm{H}_{2} \mathrm{O}$. The medium was adjusted to $\mathrm{pH} 9 \cdot 5$ with sterile $\mathrm{Na}_{2} \mathrm{CO}_{3}$. This strain grew at a temperature range of $20-44^{\circ} \mathrm{C}$ (optimum $38^{\circ} \mathrm{C}$ ), determined using a temperaturegradient incubator, and at a $\mathrm{pH}$ range of $8 \cdot 0-10 \cdot 5$ (optimum 9.0-10.0) as determined with various $25 \mathrm{mM}$ pH buffers (MES pH $5 \cdot 5-6 \cdot 5$, PIPES pH $6 \cdot 1-7 \cdot 5$, HEPES pH 6.8-8.2, Tricine $\mathrm{pH} 7 \cdot 4-8 \cdot 8$, CHES $\mathrm{pH} 8 \cdot 6-10 \cdot 0$ and CAPS $\mathrm{pH} 9 \cdot 7-11 \cdot 1)$. Routine cultivation was conducted at $38^{\circ} \mathrm{C}$ and $\mathrm{pH} 9 \cdot 5$. The requirements for $\mathrm{NaCl}$ and magnesium for growth were determined in medium containing $1 \cdot 8-5 \cdot 2 \mathrm{M} \mathrm{NaCl}$ or $0-0 \cdot 1 \mathrm{M} \mathrm{MgSO}_{4}$. Strain DZ- ${ }^{\mathrm{T}}$ showed optimal growth at 3.9-4.3 M NaCl. Magnesium was not required.

Phenotypic tests were performed according to the proposed minimal standards for the description of new taxa in the order Halobacteriales (Oren et al., 1997a). Cell motility and morphology were examined by phase-contrast and transmission electron microscopy of exponentially growing liquid cultures. Gram staining was carried out as described by Dussault (1955). Colony morphology was observed on optimal growth agar medium after incubation at $38^{\circ} \mathrm{C}$ for 4 days. Anaerobic growth was tested in the presence of $5 \mathrm{~g}$ nitrate, $\mathrm{L}$-arginine or DMSO ${ }^{-1}$ in filled, stoppered tubes. 


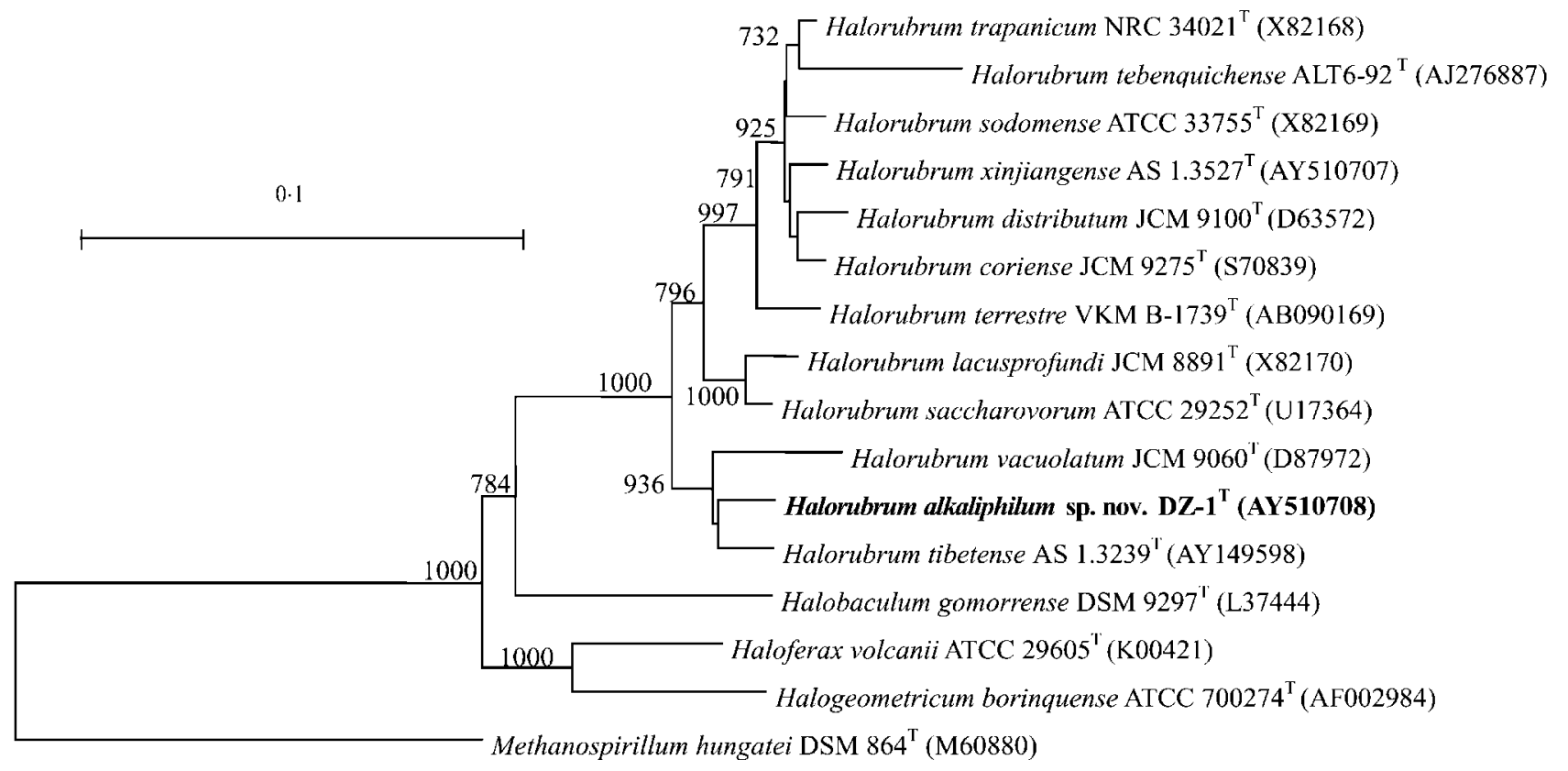

Fig. 1. Phylogenetic tree showing the position of strain $D Z-1^{\top}$ among the species representing the genus $H a l o r u b r u m$ and other genera of Halobacteriales based on their 16S rRNA gene sequences (GenBank/EMBL/DDBJ accession numbers are shown in parentheses). The 16S rRNA gene sequence of Methanospirillum hungatei DSM $864^{\top}$ was used as outgroup. The numbers at branch points indicate the level of bootstrap support, based on 1000 resamplings; values $>60 \%$ are shown. Bar, $0 \cdot 1$ expected changes per site.

Tests for catalase and oxidase activities, and hydrolysis of starch, casein, gelatin and Tween 80 were performed as described previously (Gonzalez et al., 1978). Tests for nitrate reduction, $\mathrm{H}_{2} \mathrm{~S}$ formation, indole formation and the utilization of sugars, alcohols, amino acids and organic acids were carried out as described by Oren et al. (1997a). Antibiotic sensitivity tests were performed by spreading bacterial suspensions on culture plates and applying discs impregnated with the tested antibiotics. Phospholipids and glycolipids were separated on silica gel plates $(10 \mathrm{~cm} \times$ $10 \mathrm{~cm}$ ) by TLC and were analysed according to the method of Xin et al. (2001).

The DNA base composition was determined by thermal denaturation $\left(T_{\mathrm{m}}\right)$ (Marmur \& Doty, 1962). The 16S rRNA gene was amplified under conditions described previously (Zhang et al., 2003), except that the following pair of archaeal primers was used: $5^{\prime}$-ATTCCGGTTGATCCTGCCGG-3' (nt 6-25, according to Escherichia coli numbering) and 5'-AGGAGGTGATCCAGCCGCAG-3' (nt 1540-1521). The PCR product was sequenced by GeneCore Biotechnologies (Shanghai, China) using the BigDye Terminator version 3.1 Cycle Sequencing Kit (Applied Biosystems) and an automated DNA sequencer (model ABI3700; Applied Biosystems). A BLAST search was performed to identify the nearest taxonomically identified relatives of strain $\mathrm{DZ}-1^{\mathrm{T}}$, the sequences of which were retrieved from GenBank (AY149498, H. tibetense; U17364, H. saccharovorum). Multiple sequence alignments of the $16 \mathrm{~S}$ rRNA gene sequences were performed using CLUSTAL $\mathrm{W}$ version 1.8 (Thompson et al., 1994). A phylogenetic tree (Fig. 1) was constructed using the neighbour-joining method with Kimura's two-parameter calculation model in TREECON W version 1.3b (Van de Peer \& De Wachter, 1994). DNA-DNA hybridization of strain DZ-1 ${ }^{\mathrm{T}}$ to the type strains of $H$. vacuolatum and $H$. tibetense was performed by the thermal denaturation and renaturation method of De Ley et al. (1970) as modified by Huss et al. (1983).

16S rRNA gene sequence similarity searches indicated that strain DZ-1 ${ }^{\mathrm{T}}$ was phylogenetically related to the haloalkaliphilic species of the genus Halorubrum, i.e. H. tibetense $(97 \cdot 5 \%)$ and $H$. vacuolatum $(95 \cdot 7 \%)$. Strain $\mathrm{DZ}-1^{\mathrm{T}}$ contained $\mathrm{C}_{20} \mathrm{C}_{20}$ and $\mathrm{C}_{20} \mathrm{C}_{25}$ derivatives of phosphatidyl glycerol and phosphatidyl glycerol phosphate methyl ester, but lacked phosphatidyl glycerol sulfate and sulfated glycolipid, similar to $H$. tibetense and $H$. vacuolatum. Phylogenetic tree analysis showed that strain $\mathrm{DZ}-1^{\mathrm{T}}$ and $H$. tibetense and $H$. vacuolatum were in the same cluster (Fig. 1). The lipid composition, physiological properties (see the following species description) and characteristics of the DNA molecule indicated that strain $\mathrm{DZ}-1^{\mathrm{T}}$ was a member of the genus Halorubrum and was phylogenetically close to the haloalkaliphilic species. However, strain $\mathrm{DZ}-\mathrm{I}^{\mathrm{T}}$ was distinguished from $H$. tibetense and $H$. vacuolatum in phenotypic and physiological properties: strain DZ- $1^{\mathrm{T}}$ was motile, while $H$. tibetense and $H$. vacuolatum are non-motile. Strain DZ-1 ${ }^{\mathrm{T}}$ assimilated fructose but not 
Table 1. Differentiation of Halorubrum alkaliphilum sp. nov. from other Halorubrum species

Taxa: 1, H. alkaliphilum strain $\mathrm{DZ}-1^{\mathrm{T}} ; 2$, H. tibetense AS $1.3239^{\mathrm{T}}$ (data from Fan et al., 2004); 3, H. vacuolatum JCM $9060^{\mathrm{T}}(\mathrm{Grant} \&$ Larsen, 2001); 4, H. saccharovorum ATCC $29252^{\mathrm{T}}$ (Grant \& Larsen, 2001); 5, H. lacusprofundi JCM 8891 ${ }^{\mathrm{T}}$ (Grant \& Larsen, 2001); 6, H. xinjiangense AS $1.3527^{\mathrm{T}}$ (Feng et al., 2004); 7, H. coriense JCM 9275 ${ }^{\mathrm{T}}$ (Grant \& Larsen, 2001); 8, H. distributum JCM 9100 ${ }^{\mathrm{T}}(\mathrm{Grant} \&$ Larsen, 2001); 9, H. sodomense ATCC $33755^{\mathrm{T}}$ (Grant \& Larsen, 2001); 10, H. trapanicum JCM 10477 ${ }^{\mathrm{T}}$ (Grant \& Larsen, 2001); 11, H. tebenquichense ALT6-92 ${ }^{\mathrm{T}}$ (Lizama et al., 2002); 12, H. terrestre VKM B-1739 ${ }^{\mathrm{T}}$ (Ventosa et al., 2004). ND, Not described; PGS, phosphatidyl glycerol sulfate; S-DGD, sulfated mannosyl-glucosyl-glycerol diether.

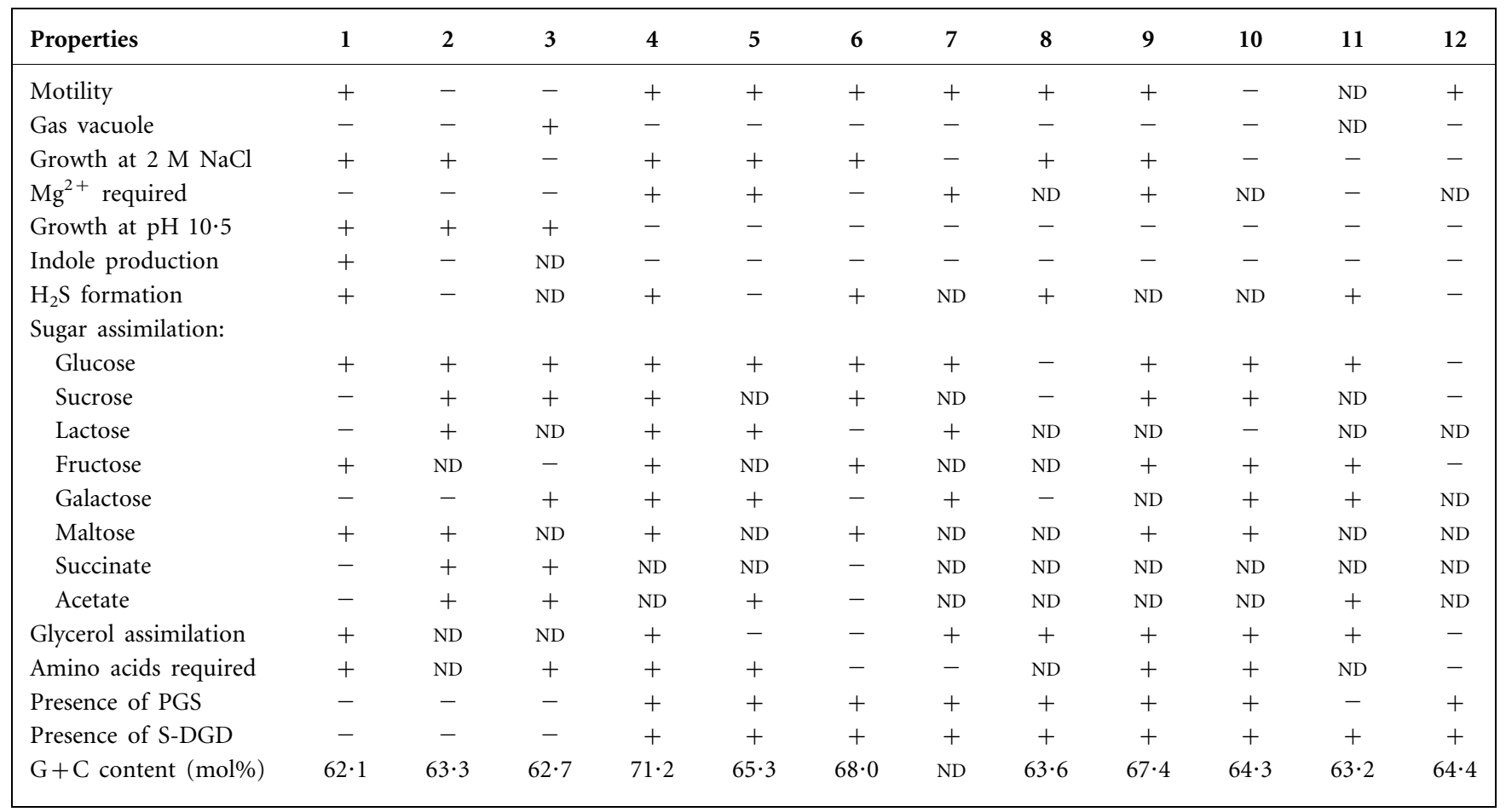

sucrose, lactose or galactose. Strain $\mathrm{DZ}-1^{\mathrm{T}}$ utilized lactate but not acetate or succinate. The characteristics of strain DZ $-1^{\mathrm{T}}$ that differentiate it from other Halorubrum species are listed in Table 1. The DNA-DNA relatedness of strain DZ- ${ }^{\mathrm{T}}$ to $H$. vacuolatum and $H$. tibetense was 13 and $22 \%$, respectively. The $\mathrm{G}+\mathrm{C}$ content of strain $\mathrm{DZ}-1^{\mathrm{T}}$ was $62 \cdot 1 \mathrm{~mol} \%$. Thus, strain $\mathrm{DZ}-1^{\mathrm{T}}$ represents a novel species of the genus Halorubrum, for which the name Halorubrum alkaliphilum sp. nov. is proposed.

\section{Description of Halorubrum alkaliphilum sp. nov.}

Halorubrum alkaliphilum [al.ka.li'phi.lum. N.L. n. alkali alkaline (from Arabic al qalí ashes of salt wort); Gr. adj. philos loving; N.L. neut. adj. philum loving, friendly to; N.L. neut. adj. alkaliphilum loving alkaline conditions].

Cells are short rods $(0 \cdot 8-1 \cdot 0 \times 1 \cdot 8-2 \cdot 0 \mu \mathrm{m})$ and Gramnegative. Colonies on agar plates containing $20 \%(\mathrm{w} / \mathrm{v})$ total salts are red, elevated and round. Growth is chemoorganotrophic, aerobic and occurs at concentrations of $1 \cdot 8-5 \cdot 2 \mathrm{M} \mathrm{NaCl}$, at $\mathrm{pH} 8 \cdot 0-10 \cdot 5$ and at $20-44^{\circ} \mathrm{C}$. Optimal $\mathrm{NaCl}$ concentration, $\mathrm{pH}$ and temperature for growth are 3.9-4.3 M, pH 9.0-10.0 and $38^{\circ} \mathrm{C}$, respectively. Magnesium is not required for growth. Catalase- and oxidase-positive. Anaerobic growth with nitrate, arginine or DMSO does not occur. Nitrate reduction to nitrite is observed and $\mathrm{H}_{2} \mathrm{~S}$ is produced from cystein. Indole formation is positive. Tween 80, casein and starch are not hydrolysed. Gelatinasenegative. Amino acids are required for growth. Fructose, glucose, mannose and maltose are utilized with the production of acids. Glycerol is utilized without acid production. No growth or acid production is observed on sucrose, lactose, raffinose, rhamnose, galactose, D-ribose, mannitol or sorbitol. Lactate and glutamic acid are utilized. Resistant to penicillin $\mathrm{G}$, rifampicin, chloramphenicol, neomycin and bacitracin. Cells contain $\mathrm{C}_{20} \mathrm{C}_{20}$ and $\mathrm{C}_{20} \mathrm{C}_{25}$ derivatives of phosphatidyl glycerol and phosphatidyl glycerol phosphate methyl ester, but lack phosphatidyl glycerol sulfate and sulfated glycolipid. The DNA G $+\mathrm{C}$ content is $62 \cdot 1 \mathrm{~mol} \%$ $\left(T_{\mathrm{m}}\right)$. Isolated from a soda lake in Xinjiang, China.

The type strain is $\mathrm{DZ}-1^{\mathrm{T}}$ and has been deposited in the China General Microbiological Culture Collection Center (CGMCC) as AS $1.3528^{\mathrm{T}}$ and in the Japanese Collection of Microorganisms as JCM $12358^{\mathrm{T}}$.

\section{Acknowledgements}

This work was supported by grants from the Ministry of Science and Technology (973 project) and the Chinese Academy of Sciences 
(KJCX1-SW-07). We express our thanks to Professor Dr H. G. Trüper at Bonn Univerisity and Professor R.-Y. Zheng at the Institute of Microbiology (Beijing) for their help with the nomenclature.

\section{References}

De Ley, J., Cattoir, H. \& Reynaerts, A. (1970). The quantitative measurement of DNA hybridization from renaturation rates. Eur J Biochem 12, 133-142.

Dussault, H. P. (1955). An improved technique for staining halophilic bacteria. J Bacteriol 70, 484-485.

Fan, H., Xue, Y., Ma, Y., Ventosa, A. \& Grant, W. D. (2004). Halorubrum tibetense sp. nov., a novel haloalkaliphilic archaeon from Lake Zabuye in Tibet, China. Int J Syst Evol Microbiol 54, 1213-1216.

Feng, J., Zhou, P. \& Liu, S.-J. (2004). Halorubrum xinjiangense sp. nov., a novel halophile isolated from saline lakes in China. Int J Syst Evol Microbiol 54, 1789-1791.

Franzmann, P. D., Stackebrandt, E., Sanderson, K., Volkman, J. K., Cameron, D. E., Stevenson, P. L., McMeekin, T. A. \& Burton, H. R. (1988). Halobacterium lacusprofundi sp. nov., a halophilic bacterium isolated from Deep Lake, Antarctica. Syst Appl Microbiol 11, 20-27.

Gonzalez, C., Gutierrez, C. \& Ramirez, C. (1978). Halobacterium vallismortis sp. nov. An amylolytic and carbohydrate-metabolizing, extremely halophilic bacterium. Can J Microbiol 24, 710-715.

Grant, W. D. \& Larsen, H. (2001). Genus VII Halorubrum. In Bergey's Manual of Systematic Bacteriology, 2nd edn, vol. 1, pp. 320-324. Edited by D. R. Boone, R. W. Castenholz \& G. M. Garrity. New York: Springer.

Huss, V. A. R., Festl, H. \& Schleifer, K. H. (1983). Studies on the spectrometric determination of DNA hybridization from renaturation rates. Syst Appl Microbiol 4, 184-192.

Kamekura, M. \& Dyall-Smith, M. L. (1995). Taxonomy of the family Halobacteriaceae and the description of two new genera Halorubrobacterium and Natrialba. J Gen Appl Microbiol 41, 333-350.

Kamekura, M., Dyall-Smith, M. L., Upasani, V., Ventosa, A. \& Kates, M. (1997). Diversity of alkaliphilic halobacteria: proposals for transfer of Natronobacterium vacuolatum, Natronobacterium magadii, and Natronobacterium pharaonis to Halorubrum, Natrialba, and Natronomonas gen. nov., respectively, as Halorubrum vacuolatum comb. nov., Natrialba magadii comb. nov., and Natronomonas pharaonis comb. nov., respectively. Int J Syst Bacteriol 47, 853-857.

Lizama, C., Monteoliva-Sánchez, M., Suárez-García, A., RosellóMora, R., Aguilera, M., Campos, V. \& Ramos-Cormenzana, A. (2002). Halorubrum tebenquichense sp. nov, a novel halophilic archaeon isolated from the Atacama Saltern, Chile. Int J Syst Evol Microbiol 52, 149-155.

Marmur, J. \& Doty, P. (1962). Determination of the base composition of deoxyribonucleic acid from its thermal denaturation temperature. J Mol Biol 5, 109-118.

McGenity, T. J. \& Grant, W. D. (1995). Transfer of Halobacterium saccharovorum, Halobacterium sodomense, Halobacterium trapanicum NRC 34021 and Halobacterium lacusprofundi to the genus Halorubrum gen. nov., as Halorubrum saccharovorum comb. nov., and Halorubrum sodomense comb. nov., Halorubrum trapanicum comb. nov., and Halorubrum lacusprofundi comb. nov. Syst Appl Microbiol 18, 237-243.

Oren, A. (1983). Halobacterium sodomense sp. nov., a Dead Sea halobacterium with an extremely high magnesium requirement. Int $J$ Syst Bacteriol 33, 381-386.

Oren, A., Ventosa, A. \& Grant, W. D. (1997a). Proposed minimal standards for description of new taxa in the order Halobacteriales. Int J Syst Bacteriol 47, 233-238.

Oren, A., Kamekura, M. \& Ventosa, A. (1997b). Confirmation of strain VKM B-1733 as the type strain of Halorubrum distributum. Int J Syst Bacteriol 47, 231-232.

Thompson, J. D., Higgins, D. G. \& Gibson, T. J. (1994). CLUSTAL W: improving the sensitivity of progressive multiple sequence alignment through sequence weighting, position-specific gap penalties and weight matrix choice. Nucleic Acids Res 22, 4673-4680.

Tomlinson, G. A. \& Hochstein, L. I. (1976). Halobacterium saccharovorum sp. nov., a carbohydrate-metabolizing, extremely halophilic bacterium. Can J Microbiol 22, 587-591.

Van de Peer, Y. \& De Wachter, R. (1994). TREECON for Windows: a software package for the construction and drawing of evolutionary trees for the Microsoft Windows environment. Comput Appl Biosci 10, 569-570.

Ventosa, A., Gutiérrez, M. C., Kamekura, M., Zvyagintseva, I. S. \& Oren, A. (2004). Taxonomic study of Halorubrum distributum and proposal of Halorubrum terrestre sp. nov. Int J Syst Evol Microbiol 54, 389-392.

Xin, H.-W., Itoh, T., Zhou, P.-J., Suzuki, K.-I. \& Nakase, T. (2001). Natronobacterium nitratireducens sp. nov., a haloalkaliphilic archaeon isolated from a soda lake in China. Int J Syst Evol Microbiol 51, 1825-1829.

Zhang, D., Yang, H., Zhang, W., Huang, Z. \& Liu, S.-J. (2003). Rhodocista pekingensis sp. nov., a cyst-forming phototrophic bacterium from a municipal wastewater treatment plant. Int J Syst Evol Microbiol 53, 1111-1114. 